\title{
Metabotropic Glutamate Receptor 3
}

National Cancer Institute

\section{Source}

National Cancer Institute. Metabotropic Glutamate Receptor 3. NCI Thesaurus. Code C114531.

Metabotropic glutamate receptor 3 ( $879 \mathrm{aa}, \sim 99 \mathrm{kDa}$ ) is encoded by the human GRM3 gene. This protein is involved in $\mathrm{G}$ protein-coupled receptor signaling. 